\title{
A política e o diabo
}

\author{
Leszek Kolakowski \\ Traduçáo de H. SIEWIERSKI
}

1.

De acordo com o ensino cristão tradicional, o diabo é incapaz de criar. Tudo que foi criado, foi criado por Deus e por esta razão é absoluta e infinitamente bom; o todo da natureza é, como uma difusão de Deus, bom por definição, enquanto a má yontade, diabólica ou humana, representa uma pura negatividade. Daí ser o diabo, para concluir sua obra de destruição, obrigado a explorar o material trazido por Deus, impedindo seu uso adequado. A sua atividade iníqua constitui inteiramente uma exploração parasitária da perfeição da Criação.

No que se refere às questões humanas, esta degenerescência consiste principalmente no fato de que o diabo - apoiando-se, evidentemente, em nossa indignidade, que é fruto do pecado original - nos tenta no sentido que tomemos os bens relativos por bens em si, quer dizer, que adoremos alguns bens secundários, como se merecessem uma veneração divina, substituindo assim o Criador por criaturas.

E nisso consiste a maioria dos nossos pecados. Os nossos impulsos naturais, instintos e desejos são bons em si e o seu uso é legítimo só na medida em que são dirigidos diretamente a Deus como bem supremo, e não por si próprios. As nossas necessidades e desejos físicos e espirituais merecem ser satisfeitos à medida apenas em que lembremos que seu fim supremo é Deus. O conhecimento é algo louvável, se usarmos a razão para penetrar os mistérios da natureza com a finalidade de melhor conhecer a ordem divina, e desse modo o proprio autor dessa ordem. Os prazeres da vida contam na medida em que servem a vida e na medida em que estamos conscientes ser a vida apenas um hino de veneração à glória do Senhor. Amamos devidamente os outros homens, se através deles amamos a Deus.

Isto aplica-se às questões políticas não menos do que a todas as outras. Na medida em que a política é puramente uma luta pelo poder, ela é por definição, em categorias da fé cristã, o domínio do diabo. Ela simplesmente liberta a nossa libido dominandi como um instinto que cresce, como se fora, por causa do seu próprio crescimento, sem ter os outros fins além de si mesmo. O domínio sobre a natureza foi um privilégio bíblico do homem; do mesmo modo é a ordem bíblica, indispensável para garantir a paz e a justiça na terra, um modo de servir a Deus e de cumprir as suas intenções. E assim, como em todos os outros domínios da vida humana, aqui também o diabo torce e envenena uma ordem boa e natural. No momento em que os bens políticos adquirem uma autonomia, tornando-se fins em si, eles passam a ficar a serviço do diabo.

São Tomás de Aquino construíra a mais esplêndida e a mais abrangente ordem conceitual a qual, sem omitir e menosprezar os bens instrumentais, os valores relativos e as causas secundárias, e assim, sem fortalecer a tentação teocrática, encontrou um lugar adequado e legítimo para todos os gêneros de atividade humana, como o conhecimento, a política, as artes ou a técnica. Sobre essa ordem estende-se uma abóbada de sabedoria e de bondade divinas, em direção à qual tudo se dirige de modo natural, como a seu

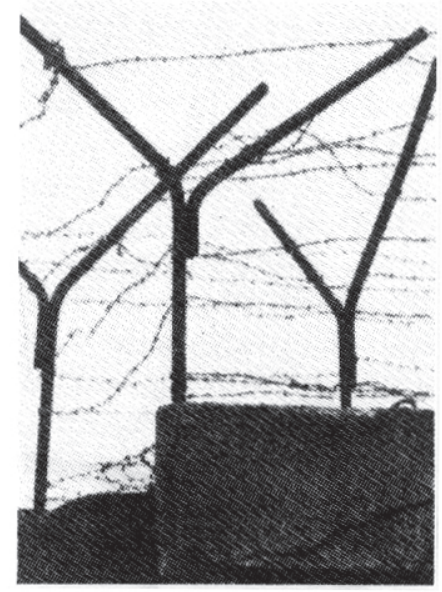

LESZEK KOLAKOWSKI é o principal cientista polftico polonês. Inicialmente marxista, tornou-se crftico dessa corrente de pensamento e escreveu o hoje clássico Principais correntes do Marxismo. Rompido com o governo comunista de seu pals, estabeleceu-se na Inglaterra e ensina atualmente na Universidade de Cambridge. O presente ensaio foi cedido pela revista Aproximaçôes. 


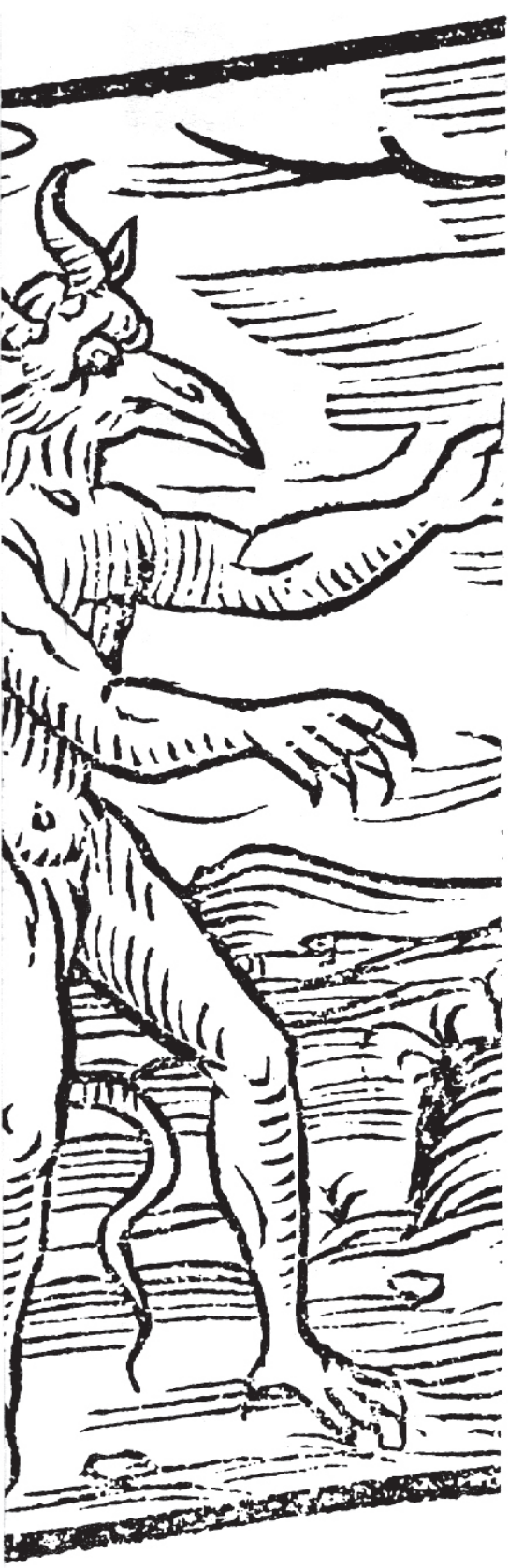

1 Summa theologiae, 1a 2ae, Qu. XCl, art. ii, Qu. XCIV.

2 "De gradibus humilitatis et superbiae", Migne, in Patrologia latina, vol. 182 pp.941-77. derradeiro fim. Nessa ordem não havia lugar algum para uma distinção aguda da lei, no sentido puramente normativo, e da lei como uma regularidade natural; das regras que se referem ao bem e ao mal, e das regras que governam a seqüência natural dos acontecimentos.

Ambos os tipos de regras tiram sua importância dos vereditos infalíveis do Ser em quem convergem sabedoria e bondade.

Mesmo se podemos, é claro, violar no nosso procedimento as regras do bem e do mal, o que não é possível fazer no caso das regularidades naturais, de modo algum fica infringida a validade da lei. A ordem natural se vinga sobre nós, quando tentamos ignorar suas leis; assim também somos punidos por Deus quando infringimos seus mandamentos. A lei natural não tem importância em si, ela procede da lei eterna: ela é o modo em que funciona a lei eterna nos seres racionais - lex est aliquid rationis, como dizia São Tomás de Aquino(1), antecipando Kant; ela (a lei natural) não pode ser anulada pelo "coração do homem".

Essa ordem elegante em que todos os domínios da vida humana, inclusive a política, encontraram seu respectivo lugar na hierarquia universal, desmanchou-se irreversivelmente (pelo menos assim parece) e gostaríamos por um momento de refletir sobre o sentido metafísico desse colapso.

Todo o desenvolvimento da modernidade, a começar de suas raízes na Alta Idade Média, pode ser entendido como um movimento gradual pelo qual a política, a arte, a ciência e a filosofia firmaram seu status autônomo e independência em relação âs supervisões divina e eclesiástica. Cada uma dessas disciplinas teve que procurar os seus próprios critérios de validade, em vez de tirá-los da tradição bíblica e do ensinamento da Igreja. Deixou então de ser evidente onde essa base normativa devia ser descoberta e como as diversas disciplinas do pensamento e da ação pudessem produzir ex nihilo seus próprios princípios, sem torná-los simplesmente uma questão de escolha arbitrária ou de capricho, e sem tirar finalmente a conclusão que não existe nenhum desses princípios. Esse último grau de libertação niilista foi definitivamente conseguido na arte, num grau menor na filosofia, mas não em ciência, enquanto nas doutrinas políticas não foi aceito sem ambigüidades por todos, embora as análises de Maquiavel e de Hobbes muito se tenham aproximado a essas conclusões extremas.

Poder-se-ia esperar que, segundo os ensinamentos cristãos (e especialmente agostiniano), cada domínio da vida tornar-se-ia vítima do diabo se conquistasse autonomia e produzisse todos os vereditos a respeito do que nele é bom, importante, perfeito ou próprio. Esses vereditos - poder-se-ia deduzir - se tornam então uma questão de livre escolha do homem, e a escolha do homem que não seja iluminada pela graça se inclina, de uma forma natural, para o mal. Se fazendo essa escolha sucumbimos realmente à tentação do diabo ou antes à nossa própria natureza corrupta, o resultado, em todo caso, fortalecerá inevitavelmente forças diabólicas.

Se em vez de edificar moralmente os homens e introduzi-los aos segredos da verdade cristã, a arte se torna objeto de puro divertimento, de experimentação formal, de uma expressão pessoal desembaraçada ou simplesmente de lisonja dos gostos impuros do público, ela não será apenas moralmente indiferente, mas favorecerá necessariamente o pecado. Quando o conhecimento leigo, em vez de tentar desvendar no mundo a sabedoria do Criador, não respeita a verdade revelada, satisfazendo apenas a curiosidade humana, ele se torna inevitavelmente um instrumento do ateísmo. Assim São Bernardo, no seu tratado sobre os graus da soberba (hybris), menciona a curiosidade entre os sintomas desse grande pecado ${ }^{(2)}$ e a mesma opinião repete-se na literatura da devoção.

No que se refere ao mal da política secular ele é tão evidente e clamoroso do ponto de vista da tradição de sabedoria cristã, que não há necessidade de insistir sobre esta questão. Se os negócios da política não têm sua base na lei natural, que procede por sua vez da legislação divina, então parece óbvio que não existe absolutamente razão alguma para que seja louvada a justiça (qualquer que seja o seu significado) mais do que a injustiça; e a comunidade política não teria outra base do que o movimento incontrolável das paixões cegas, em conflito.

A paz não poderia ser nada mais do que um equilíbrio provisório de forças mecânicas, e a justiça seria reduzida às tentativas infinitas das partes em conflito forçar concessões umas das outras. Havendo abandonado os Evangelhos, os pensadores políticos podiam, sem dúvida, continuar a referir-se a Aristóteles, o que na realidade fizeram. Mas Aristóteles, mesmo sendo venerado pelos filósofos cristãos e não-cristãos, não tinha autoridade divina e não era de modo algum infalível - podia-se impunemente reagir

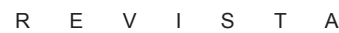


a seus conselhos com um simples encolher dos ombros.

Que tenha sido este realmente um modo de pensar normal no ensino da Igreja, fica demonstrado pelos incontáveis documentos, oficiais e meio-oficiais, e um notável corpus da literatura cristã sobre o tema. Poder-se-ia asseverar que a filosofia de Hobbes foi de certo modo um triunfo do Cristianismo. Dessa filosofia resultava que todas as regras normativas da política, no momento em que rompem os laços com sua base religiosa, desaparecem necessariamente, e entảo todo o tecido da sociedade se sustenta apenas numa simples composição de forças, governadas pelo medo, ganância e cobiça do poder, simplesmente porque é assim o mundo organizado.

Se a supremacia da lei divina em todas as áreas da vida humana, inclusive em política, faz parte indispensável do ensino cristão, se nenhuma ordem política pode ser válida (ou pelo menos, explicitamente, um fragmento da ordem divina que abrange tudo); se a vida social, privada desta legitimidade, logo desliza nas garras de satanás - então se deveria supor que a Igreja não pode, sem ser inconseqüente, renunciar`as pretensões de supremacia sobre as autoridades estatais, e até que deveria, de acordo com sua doutrina, aspirar à teocracia, para não se render ao príncipe deste mundo.

Se assim for, como entender então todas as declarações recentes da Igreja e dos papas, principalmente após o Concílio Vaticano II, que explicitamente renunciam às pretensões teocráticas, aceitando a autonomia da ciência, etc.? Será que não são simplesmente concessões forçadas ao "espírito do tempo" e à modernidade? E será que não são contrárias a toda a tradição cristã?

Todavia alguns teóricos da lei natural, entre os deístas e ateístas dos séculos XVII e XVIII, sustentaram a opinião que, graças a uma intuição congênita, temos um acesso direto ao conhecimento da lei natural, sem participação necessária da Revelação. Sabemos simplesmente por instinto o que é certo e o que não é, o que é justo e o que é injusto, porque a própria natureza inscreveu nas nossas mentes esse tipo de intuição. Tudo isso reduzia-se à afirmação que a presença de Deus e da Sua Lei não têm importância para os princípios de justiça, porque esses princípios se sustentam em seus próprios pés, independentemente da existência ou não-existência de Deus.

Essa fé, no entanto, era sujeita a uma erosão natural de parte dos mais simples argumentos céticos, assim como do fato - tanto mais evidente quanto mais se conhecia as outras civilizações - de que os conceitos de justiça e do direito natural não são de modo algum universais, nem histórica nem geograficamente, e que então não podemos ter certeza estejam eles imutavelmente gravados no coração humano.

Desde que a luta dos reis e dos príncipes contra o papado manifestava-se não só em ações políticas práticas, mas criando também a sua base teórica, podia-se encontrar, entre os adeptos da política leiga e da autonomia do poder estatal, uma certa inquietação em face de uma ordem política desprovida da sanção celeste.

Esses receios manifestaram-se na opinião de que é certo e útil para os soberanos políticos que não acreditam em Deus, nem na vida após a morte, o uso dos símbolos religiosos e rituais, das sanções eclesiásticas e divinas em favor dos seus próprios interesses e para garantir a ordem pública. Marsilio de Pádua exprimiu esta opinião bem claramente, e Maquiavel, evidentemente, ainda mais ${ }^{(3)}$. Do mesmo modo Hobbes, e - não tão claro mas indubitavelmente - Spinoza o qual, além disso, dizia que é preciso governar os homens de tal forma que acreditem estar se autogovernando. O próprio Montesquieu acentua, pela boca de seu Uzbeque, que se a justiça dependesse das convenções dos homens essa verdade terrível deveria ser escondida até perante si mesmo ${ }^{(4)}$.

A razão desse uso fraudulento da religião para fins políticos era a seguinte: a maioria dos homens ou é estúpida ou infame, ou uma coisa e outra, tanto que sem a ameaça do inferno não seria possível dominar suas cegas paixões as quais representam um perigo constante para a ordem pública. Se Deus era considerado um juiz supremo, o diabo, como um executor dos seus vereditos, parecia excitar a imaginação num grau bem maior. Os teóricos políticos dessa orientação estavam partindo do princípio que, se o diabo não existisse, seria necessário inventá-lo.

Embora esses professores, totalmente "secularizados", confirmassem, involuntariamente, a doutrina cristã, segundo a qual a política não pode dispensar uma justificação religiosa, isto não significava que o padre ou o papa devessem controlar o imperador ou o príncipe - ao contrário, o príncipe é que devia empregar o padre. Desse modo afirmava-se que uma ordem política saudável exige uma proteção divina - se não real, então pelo menos imaginária. Assim uma teocracia (embora não clerocracia) desnaturada parecia encontrar o apoio de parte até dos mais inconciliáveis inimigos da Igreja.

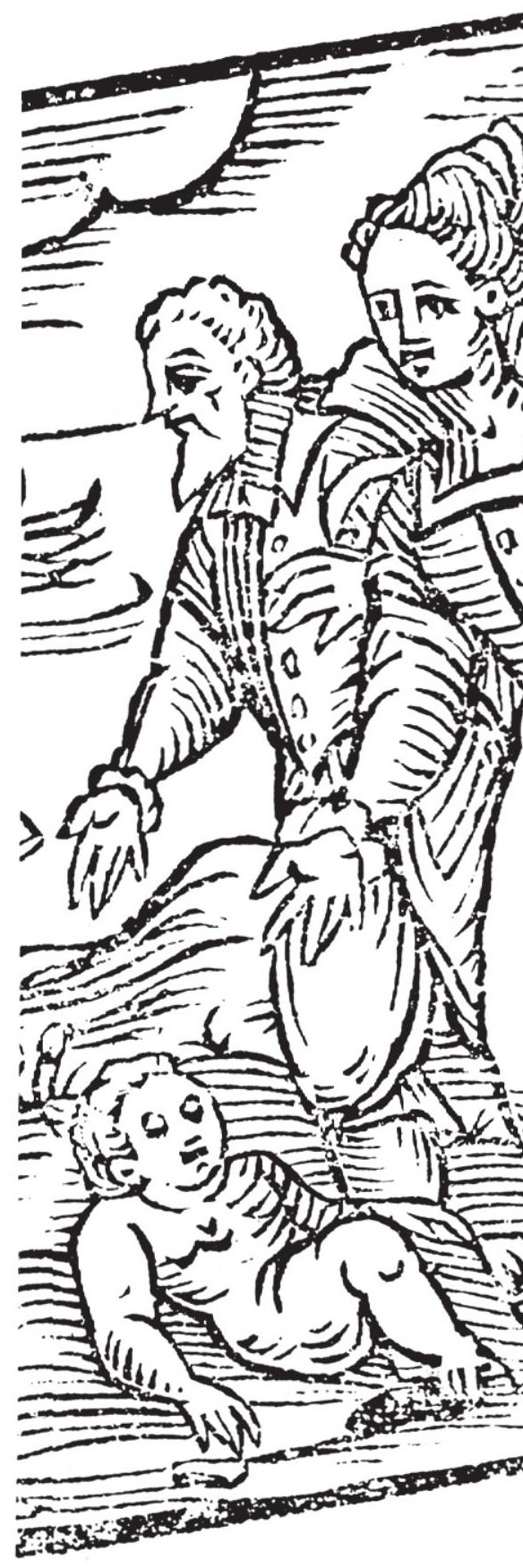

3 Defensor of peace, 1,5,11; Discourses, I, 11-15.

4 Lettres persanes, LXXXIII. 

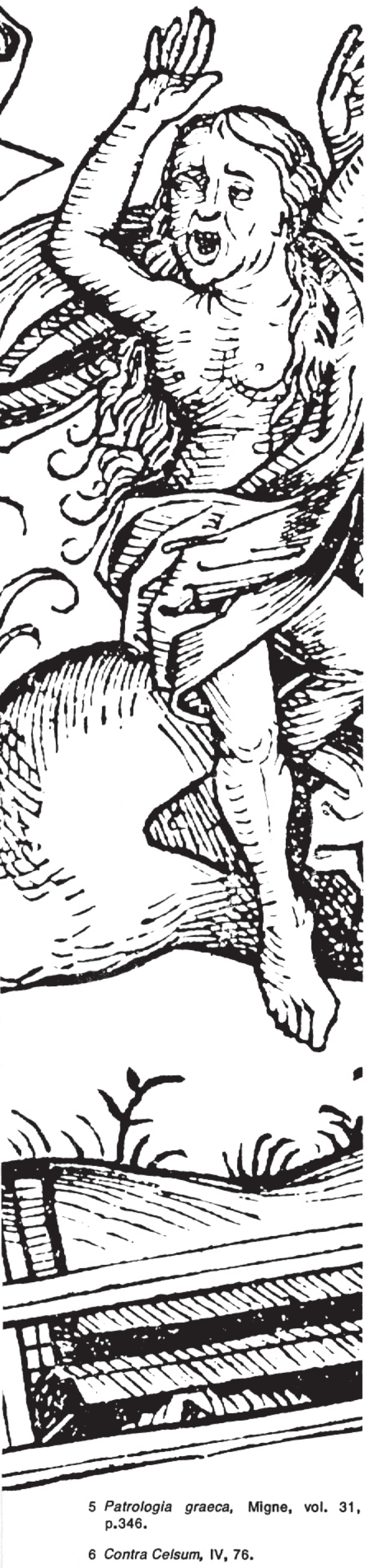

2.

Existe, no entanto, mais um aspecto nessa história. O diabo tenta - muitas vezes sem sucesso - transformar o bem em mal, mas Deus não fica parado e sabe como superar o inimigo e fazer do mal, da desolação e da destruição instrumentos dos seus próprios fins. O diabo talvez tenha conseguido derrubar um sistema saudável que manteve a política na dependência correta, fazendo com que o poder do imperador privado da consagração papal fosse condenado ao fracasso. Pode ser que tenha conseguido conferir a independência e o direito de autodeterminação tanto à esfera da política, como às artes, à ciência e à filosofia - ou pelo menos tirar os proveitos da independência delas. Mas este mundo fragmentado nunca escapou do controle divino - e da desordem sempre surgira uma ordem nova cuja função era impossibilitar a realização dos planos do diabo e iniciar os novos confrontos.

Para entender o comportamento de Deus, é preciso levar em consideração as razões pelas quais Ele não pode simplesmente mandar o diabo desaparecer ou pô-lo em ferro e torná-lo inofensivo. A resposta que a teodicéia cristã repete há séculos diz: a razão e a capacidade de fazer o mal (quer dizer a liberdade) não podem ser separados; segue-se então que Deus, criando os seres racionais - humanos e angélicos - tinha que tolerar inevitáveis maus efeitos.

Esse âmago da teodicéia já estava bem formado no pensamento cristão primitivo. Toda a teodicéia cabe virtualmente numa observação da homilia de São Basílio, o Grande, segundo o qual culpar o Criador por não nos ter criado incapazes de pecar é antepor a natureza irracional e passiva à natureza racional, ativa e livre ${ }^{(5)}$. Orígenes, que mais cedo chegou a uma conclusão parecida, afirma que se os seres humanos sao fracos, se têm que sofrer e trabalhar para sobreviver, é porque quis Deus que usassem sua invenção, sua capacidade e sua inteligência, o que não seria possível se tivessem tudo em abundância, deliciando-se com a vida ociosa ${ }^{(6)}$. Em poucas palavras, se o sofrimento que a Natureza impõe ao gênero humano é a condição do progresso, então o sofrimento que os homens infligem uns aos outros é o resultado da sua capacidade de fazer mal, e essa capacidade faz parte indispensável da existência como seres livres, e por isso também capazes de fazer o bem.

A tese principal da teodicéia cristã reduz-se ao seguinte: a obra da criação é um ato do amor, e um amor recíproco entre o Criador e Suas criaturas é concebível sob condição de que sejam essa últimas seres dotados de razão, capazes de fazer o bem pela sua própria vontade. Os atos bons obrigatórios não são, no sentido moral, bons de modo algum, e a capacidade de fazer o bem pela sua própria vontade implica a capacidade de fazer o mal. O Criador que ama é então concebível apenas sob a condição da existência do mal - pois sem o mal, a obra de criação não teria sentido. Mesmo as teodicéias mais antigas admitem, implicitamente, que Deus, forçado pelas normas de coerência lógica, não é capaz de produzir mundos que se contradigam interiormente.

Assim, como resultado de necessidade lógica, o curso dos acontecimentos no mundo consiste num jogo contínuo em que o bem e o mal querem se superar um ao outro pela astúcia. Só a Revelação, evidentemente, nos pode prometer termine esse jogo com uma vitória definitiva do bem.

3.

Mesmo se supusermos que tenha sido o diabo - com o seu trabalho paciente e pesado - quem privou a Igreja de seu poder terreno, fazendo com que a política, tanto como atividade prática quanto como esforço teórico, se tornasse independente, pelo menos na civilização ocidental, das instituições e doutrinas religiosas, mesmo assim seria natural refletir sobre as reações de Deus. No entanto, não é tão evidente que esse processo da "autonomização" tenha sido iniciado unicamente pelo diabo. Não há dúvida que o processo graças ao qual a política, a ciência, a filosofia e a tecnologia ganharam sua independência e tenham tido que criar os seus próprios alicerces, em vez de os receber inteiramente prontos da herança religiosa, foi uma condição absoluta de todos os sucessos e fracassos da modernidade. A libertação da tutela da religião foi uma condição indispensável à expansão posterior do potencial criativo da humanidade. Essa história pode ser então considerada, em termos cristãos, como a felix culpa, como a repetição do pecado original. Se ele não tivesse sido cometido, o primeiro casal continuaria num estado de inércia sem saída, produzindo uma espécie privada de história e de criatividade.

Embora o Iluminismo tenha concedido autonomia a todos os ramos da atividade dos homens, não foi capaz de impedir que o mal neles se instalasse. Mas gozando de auto- 
nomia, as ações humanas caíam inevitavelmente em conflitos recíprocos, o que produziu uma espécie de sistema metafísico de checks-and-balances. A religião já não tenta mais (na civilização ocidental) impor suas regras à ciência, às artes e à política. Como resultado, os diabos enviados a esses campos particulares da vida não podem cooperar tão facilmente, enfraquecendo desse modo a eficiência da sua ação.

À primeira vista a política parece ser (logo após o sexo) o campo de ação predileto do diabo, dado que é ela diretamente responsável pelas guerras, perseguições e todos os imagináveis e inimagináveis horrores que traz consigo a luta pelo poder. Mas em um processo histórico nunca temos certeza onde ficam as responsabilidades mais remotas. A arte, a ciência e a filosofia parecem relativamente inocentes, mas pode ser que sua inocência seja enganadora, pois atuam numa escala do tempo muito maior e seus maus efeitos são por isso muitas vezes diluídos, difíceis de detectar, incertos e inatingíveis. Os demônios do departamento da política podem ser os ruões ou noviços, enquanto seus colegas que atuam nas artes, na filosofia e na ciência têm que ser muito mais inteligentes, sutis e mais clarividentes. O mal criado pelos tiranos e conquistadores é intencional, fácil de ser identificado e, em parte, até mensurável. Mas quem seria capaz de identificar e medir o mal que nasce ao longo dos séculos do trabalho criativo dos grandes filósofos e artistas como Platão, Copérnico, Descartes, Rousseau ou Wagner? Que mestre precisa ser esse para envenenar sutilmente os frutos do trabalho de todos os nobres e sábios benfeitores da humanidade, para prever e controlar as mutações da mente humana provocadas por suas obras, e explorar estas mutações em proveito do inferno!

\section{4.}

Esta descrição poderia sugerir que a aspiração pela teocracia está embutida no tecido do Cristianismo e que foram precisamente as forças diabólicas que a impossibilitaram. Isso, porém, não é seguro, nem mesmo provável.

Ao contrário de tudo que sabemos sobre as pretensões da Igreja de dominar o mundo, o Cristianismo nunca foi teocrático no rigor da palavra. A Igreja dos mártires com certeza não foi. Os cristãos tinham uma inclinação natural a se considerar um enclave estranho no mundo pagão e a ver no poder secular um inimigo natural. Mas mesmo a Igreja triunfante, no auge da sua potência, não pode ser chamada de teocrática.

Indubitavelmente, um documento oficial famoso que exprime as pretensões teocráticas da forma mais acentuada, e é geralmente citado neste sentido, a bula Unam Sanctam do papa Bonifácio VIII (1302) diz claramente que a espada física deve ficar subordinada à espada espiritual; e que no que se refere à salvação, todos os seres humanos estão sujeitos ao papa. A base doutrinária dessas pretensões é uma capacidade ilimitada da Igreja de determinar o que é pecado e o que é virtude. Em todos os casos ligados ao pecado que exigiam a sua supressão - com a espada, se fosse necessário -, as autoridades civis eram obrigadas a servir a Igreja. Na prática, a extensão das pretensões reais do papa dependia das circunstâncias históricas, casuais: $Q$ que cada vez era designado como "as coisas espirituais" nunca podia ser livre de ambigüidade, porque a maior parte das ações dos homens tem, pelo menos potencialmente, um aspecto moral. As duas afirmações: "a Igreja não tem poder em questões seculares" e "a Igreja tem poder em questões espirituais" - pareciam logicamente coerentes ou complementares. Se, no entanto, há muitas maneiras de separar essas duas áreas, sabemos que na prática elas colidem uma com a outra. Os que usam a primeira fórmula querem restringir ou até abolir o poder da Igreja, enquanto os adeptos da segunda fórmula querem alargar o seu domínio. Em termos teóricos, tudo depende do critério por meio do qual se distingue as coisas temporais das coisas espirituais. Supondo entretanto que nosso procedimento nesta vida é relevante de um ou de outro, para nossa salvação, as pretensões teocráticas bem parecem justificadas.

Pode-se, no entanto, argumentar convincentemente não só de que elas não são apenas justificadas, como também que as aspirações semiteocráticas foram introduzidas no Cristianismo como resultado da sofística do diabo. Mesmo as mais ousadas pretensões ao poder secular - seja nas declarações teóricas como na Unam Sanctam e nas obras do Aegidius Romanus, seja na prática política do papado, digamos ao tempo de Inocêncio III - não foram, estritamente dito, teocráticas. Nunca se pretendeu substituir o poder do rei, do príncipe ou o poder judicial por um poder direto do clero, assim como nunca se tentou abolir a diferença entre os dois tipos do poder.

A mais freqüentemente citada base bíblica da divisão do poder foi, evidentemente, o dito de Jesus: "Dêem a César..." (Mateus 22, 15-22, 13-17). Sabemos pelos Evange-

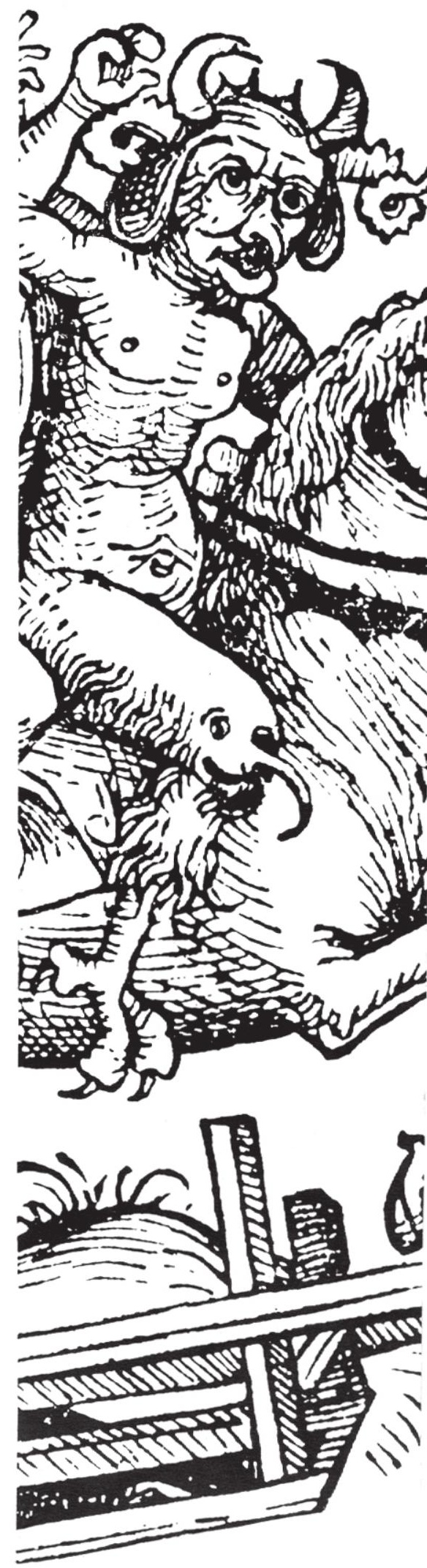



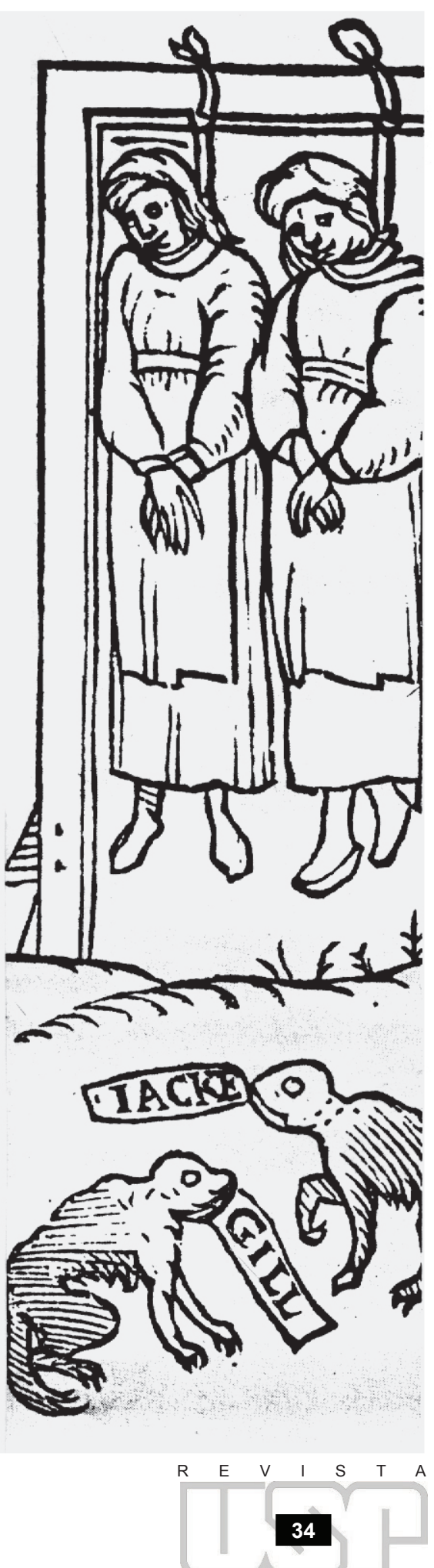

lhos que dessa forma Jesus escapou da ratoeira preparada pelos fariseus. Não é difícil de adivinhar que tipo de ratoeira era essa. Se Jesus dissesse: "não, vocês não podem pagar os impostos", admitiria abertamente que era um rebelde. Mas se dissesse: "sim, paguem os impostos", tornar-se-ia um legalista e colaborador. Sua resposta tinha que ser necessariamente ambígua. A interpretação que a considerou uma teoria geral das duas origens legítimas do poder, plenamente ou parcialmente independentes, foi uma exegese bombástica e deformatória. Mesmo assim o dito de Jesus está totalmente de acordo com Seu ensino se apenas significa: dêem a César os bens terrenos que ele está desejando pois seu poder é, de qualquer maneira, curto em face do Reino de Deus que está chegando; César não tem importância, sua glória desaparecerá brevemente sem deixar vestígios. O Apocalipse que está chegando constitui o âmago sempre forte da mensagem de Jesus.

Jesus na verdade não proporcionou seus díscipulos nem com aspirações teocráticas, nem lhes deixou uma teoria clara da dupla origem do poder, qualquer que fosse sua definição. Pregava as regras morais de validade universal. É então natural que seus sucessores devessem proferir sentenças morais sobre todas as questões em todos os campos da vida, incluindo a política, a guerra, o sexo, o comércio e o trabalho. A sua função era dizer o que é bom ou mau. No ensino de Jesus não existe base alguma que permita o uso da força ou da violência para impor - direta ou indiretamente - as leis do mestre. De fato, o ato moralmente bom, feito sob coerção física, constitui uma contradição evidente.

\section{5.}

O diabo nunca dorme, mas Deus também. A história geral da luta entre eles no campo aqui examinado pode ser apresentada do modo seguinte:

O diabo instigou a perseguição aos cristãos, mas este seu ataque direto acabou por ser ineficiente. O sangue dos mártires, conforme a profecia, fertilizou o solo em que ia o Cristianismo florescer. No momento em que o Cristianismo revelou-se vencedor, o diabo decidiu depravá-lo, inoculando-lhe a tentação da glória do domínio sobre o mundo e tentação de converter os homens pela espada: ele convenceu a Igreja que ela devia apoderar-se das instituições políticas. Se se deve venerar apenas a Deus, e a veneração de qualquer outra coisa é pecado a ser extirpado - raciocinava o diabo -, então a atividade política não pode ter seus próprios objetivos, mas tem que tomá-los da Igreja, subordinando-se aos seus vereditos.

Este foi o non sequitur enganador, inculcado ao Cristianismo pelo diabo com uma eficiência realmente assustadora. Mas o sucesso não foi total - o Cristianismo possui umas barreiras embutidas que o protegem de pretender uma teocracia total. Uma dessas barreiras é essa falsa interpretação da reflexão de Jesus sobre a moeda romana, a interpretação que sugere possuir a política secular leis bem fundamentadas dentro da sua própria área, e por isso um certo nível de autonomia. (A interpretação para mim mais convincente seria uma barreira mais forte mas esta, que prevalece, foi também eficiente.)

A outra barreira contra a impostura diabólica é uma fé poderosa na existência do diabo, do mal e do pecado original. A teocracia é uma utopia cristã (ou antes pseudocristã), um sonho do mundo perfeito, construído na terra sob a supervisão da Igreja para acabar com o pecado, ou pelo menos com a capacidade pecaminosa. A herança do Evangelho, assim como da Igreja dos mártires, constitui um apoio contra as miragens utópicas; ela lembra que o sangue dos mártires será derramado aqui e acolá até o final dos tempos, e que o mal não pode ser abolido, qualquer que seja nossa resistência. $\mathrm{O}$ paraíso na terra - moral ou material -, antes da Segunda Vinda, é um produto supersticioso da presunção humana.

O sonho teocrático contém, implícita ou explicitamente, uma visão da humanidade que se livrou das contingências, do risco e também da liberdade - a visão da perfeição imóvel que priva os homens da possibilidade de pecar e por isso mesmo da liberdade: no ensino cristão não se pode separar uma coisa da outra. A autonomia relativa da política tem que ser aceita como um componente de uma imperfeição humana inevitável. A tentativa de abolir essa autonomia pela força causaria um mal incomparavelmente maior. A Igreja como corpus mysticum é talvez infalível mas cada sacerdote é falível e pecaminoso - assim também a Igreja como um organismo sublunar. A concentração de todo poder nas suas mãos traria efeitos catastróficos para o progresso da humanidade, tanto quanto para o próprio Cristianismo. É claro que o diabo sabia disso. Pois a sua 
primeira prova de força na era cristã ocorreu cerca de 30 d.C., na tentação de Jesus com a perspectiva do reino e do esplendor terrenos. Jesus não cedeu, mas a maioria dos homens com certeza cederia.

Não obstante, a aspiração à teocracia foi forte, embora nunca total. Ela não ficou enraizada nem na doutrina, nem na interpretação errada do Evangelho, mas no próprio fato do poder secular cair nas mãos da Igreja como resultado de uma série de acontecimentos históricos.

6.

E assim estamos chegando à terceira fase da batalha. Ela devia abrir novas perspectivas para o desenvolvimento da humanidade e consistia em dispersão progressiva do poder, assim como em concessão de uma independência cada vez maior à política e aos outros campos de expansão da energia dos homens. Ia ser um jogo perigoso. Deus usou uma tática que, como sabemos pelo Velho Testamento, já tinha sido experimentada muitas vezes, atormentando o seu povo com os desastres e guerras provocadas por inimigos do povo e Dele próprio. Nos tempos modernos Ele não tinha, aparentemente, outra escolha, supondo que continuasse se recusando a melhorar a rą̧a humana, privando-a da liberdade. Mais uma vez Ele tinha que nos castigar por causa das nossas infâmias, servindo-se dos seus próprios inimigos, quer dizer, do Iluminismo.

A missão do Iluminismo foi, entre outras, a de livrar a política das cadeias da religião. Desde que a religião, assumindo tantas responsabilidades políticas e tanto poder, ficou cada vez mais contaminada por interesses seculares, cada vez mais envolvida em escândalos militares, intrigas diplomáticas e acumulação das riquezas pelas próprias riquezas, a outra parte dessa tarefa consistiu na purificação do próprio Cristianismo, e em sua redução àquilo que era seu verdadeiro interesse. Essa parte coube ao movimento reformista dentro da Igreja. De novo, os dois lados da mesma moeda romana.

Como se poderia esperar, o diabo operou incansável dos dois lados da barricada e com bastante sucesso. Dentro do próprio Iluminismo, a idéia era convencer os homens que não basta livrar a política da supervisão religiosa e separar o Estado do Igreja, e que o progresso da humanidade depende do esquecimento de toda tradição religiosa com o uso da violência, se for necessário. Ele deu ao Iluminismo uma forma anticristã elaborando, com a ajuda de muitas mentes excelentes e honestas, a idéia do humanismo que se definia sobretudo pelo ateísmo. Assim abriu a porta ao conceito da política como luta pura e simples pelo poder - o poder considerado bem supremo em si mesmo. Isso de muito ultrapassou a tradição aristotélica.

Mas esta foi a metade mais simples e não tão complicada do trabalho do diabo. Destruir totalmente e ao mesmo tempo explorar o ideal do Cristianismo que, livrando-se da poluição secular, retornaria à pureza original, foi uma tarefa muito mais difícil. O diabo provou que estava à altura do desafio.

As saudades da inocência da fé apostólica e do princípio não corrompido dos Tempos Novos configuraram a mensagem ideologicamente mais poderosa das heresias populares medievais (inclusive da Grande Reforma). E o destino da Reforma ia mostrar como o diabo converteu em proveito próprio as divisas, aparentemente intocáveis, da Igreja pobre, da Igreja que não aspira ao poder e à glória temporais.

Isso aconteceu apenas alguns anos depois da entrada espetacular de Lutero para a história européia. Uma vez que se admite ser o objetivo do Cristianismo a salvação da alma individual e, segundo Lutero, a salvação é uma questão de fé, e a fé um dom de Graça, e desde que nem o padre, nem o papa ou a Igreja como um todo têm poder de absolvição, a conclusão natural é que a Igreja visível nada tem a fazer e deve ser liquidada.

Vários radicais da Reforma tiraram realmente essa conclusão, acusando Lutero, que não seguiu o mesmo caminho, de ser inconseqüente. No início, Lutero pensou apenas no conserto da consciência dos cristãos, parecendo supor que o mundo, incuravelmente corrompido e governado por satanás, não dá para ser reformado. Mas uma vez que, apesar disso, haja decidido reformá-lo, foi obrigado a fazer compromissos. Nenhum material é perfeitamente plástico e quando queremos moldá-lo, conforme nossa visão, temos que levar em consideração as suas qualidades imutáveis, isto é, desistir da forma ideal em favor da possível, procurando um compromisso entre o produto sonhado e o material concretamente trabalhado. Temos que abandonar a dicotomia radical "tudo ou nada" e tentar melhorar o mundo, admitindo assim, implicitamente, que ele pode ser melhorado e não está irrecuperavelmente podre. Mas mesmo que a Reforma luterana tenha
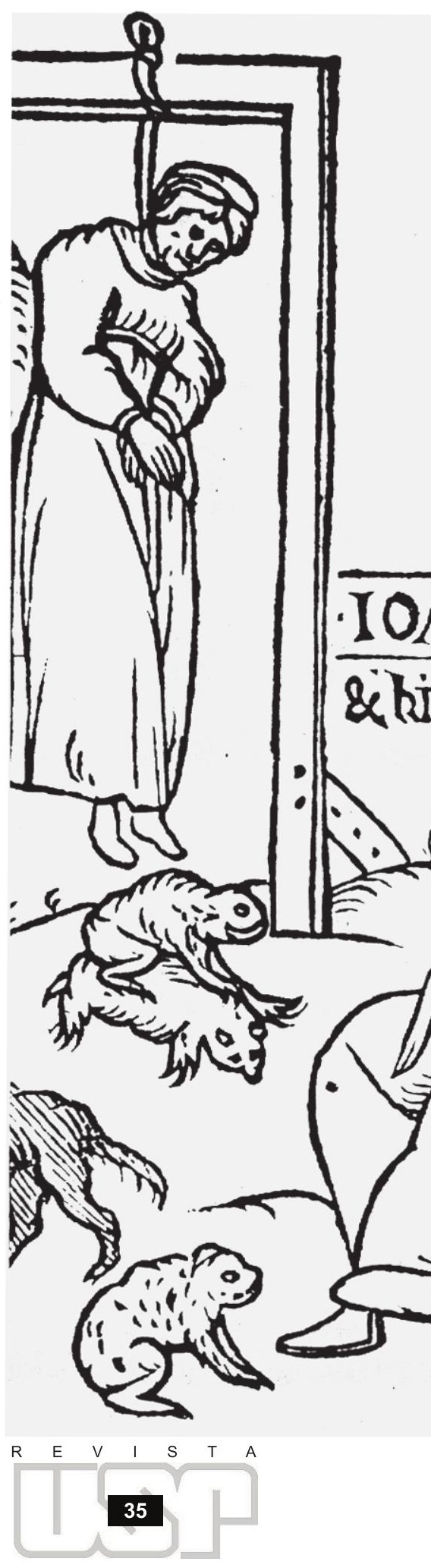


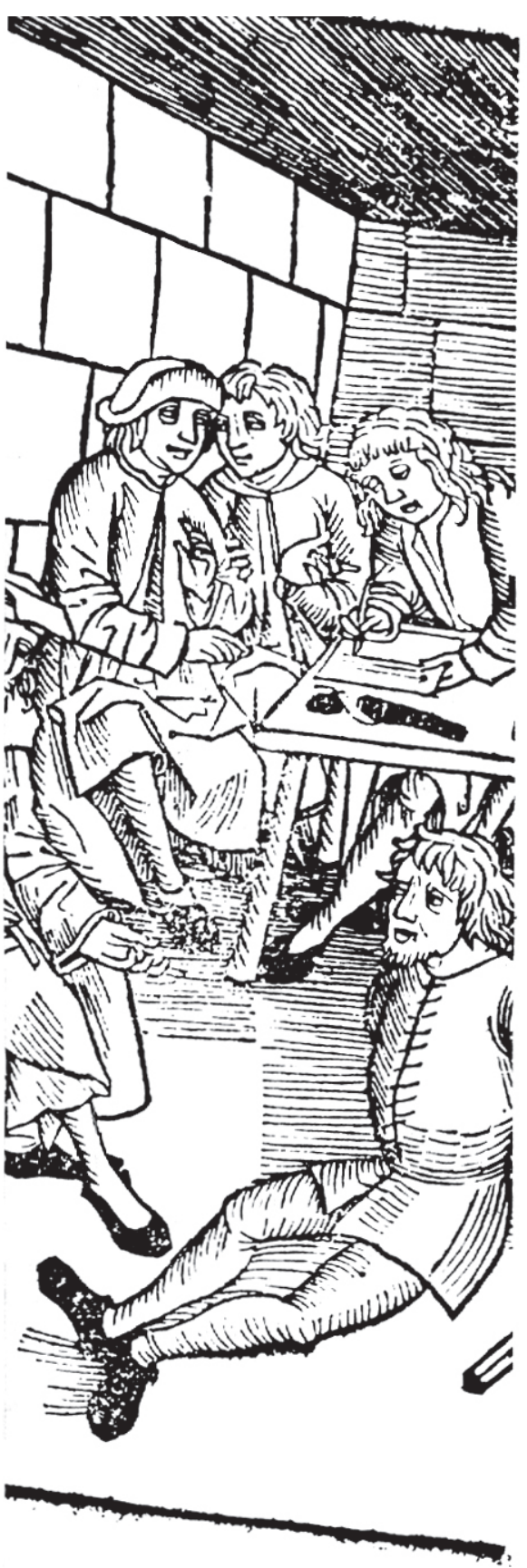

aceito a necessidade da existência da Igreja visível, ela interrompeu a sua continuidade, protegida por Deus, extingüindo o sacramento do sacerdócio e a sucessão apostólica. A Igreja se tornou um ramo da vida secular. Daí a conclusão de que a Igreja deve ser subordinada ao poder secular. $\mathrm{E}$ foi isso que eventualmente aconteceu.

Foi um triunfo impressionante do diabo. Começando com ataques ao Cristianismo, corrompido pela paixões terrenas e os negócios, assim como ao poder secular da Igreja, a Reforma acabou por adotar uma idéia que de forma perversa colocou a teocracia de pernas para o ar: fez da Igreja uma servidora do poder secular.

Mas isso não foi ainda tudo. A Igreja ia ser nacionalizada (isto é, secularizada ou destruída) e, como reverso da mesma moeda, o poder secular foi santificado e ganhou dignidade divina. Esta santificação do poder secular abrangeu todos os seus lados (como nos mostra o famoso tratado de Lutero sobre o poder estatal, de 1523). O Estado obviamente precisa não só de artesãos e camponeses, mas também de juízes, carrascos e soldados, e por isso ser carrasco não é menos digno do que ser sapateiro. Lutero argumentava, com consistência impecável, que se Jesus Cristo não foi sapateiro nem carrasco, foi porque tinha outras ocupações. Em outras palavras: é possível imaginar Jesus Cristo como carrasco! (O seu pai terreno era carpinteiro e parece possível que Jesus, antes de partir para sua missão na Galiléia também exerceu a profissão de carpinteiro. É uma profissão bem estimável, por que não carrasco então?...)

Mas havia mais. A Reforma secularizou o Cristianismo não só como instituição, mas também como doutrina, o que é equivalente a um golpe certo no próprio coração, pois os fundadores dessa doutrina não podiam imaginar coisa mais abominável. Nesse ponto as façanhas do diabo foram realmente espetaculares. Eis como ele procedeu.

Para restituir à vida cristã a sua pureza primitiva, a Reforma rejeitou totalmente a tradição guardada nas declarações dogmáticas dos papas e dos concílios, como uma fonte separada da autoridade, ao lado da Bíblia. A Escritura ia agora ser a única norma da fé. Mas então surgiu a questão de saber quem é autorizado a interpretar as Escrituras. Em princípio cada um, se escutar a voz do Espírito Santo, é capaz de fazê-lo. Mas desde que cada um, inclusive os hereges ou possuídos pelo diabo, pretenda a uma revelação ou inspiração especial e nenhum padrão obrigatório possa ser estabelecido, a Igreja como comunidade organizada não poderia subsistir. Assim os exegetas, sem encontrar apoio na continuidade da autoridade eclesiástica, historicamente formada, não tinham outro instrumento de interpretação da Sagrada Escritura senão a sua própria razão, aliás condenada, considerada corrupta e dominada pelo diabo. Como resultado disso, a Reforma produziu - em ofuscante oposição à sua intenção original - idéia horrível de religião racional. Ela ia se tornar a sementeira do deísmo e do racionalismo.

Em sua Histoire des variations des eglises protestantes (1688) - a obra-prima da Contra-Reforma -, Bossuet compreendeu essa questão com uma clareza digna de louvor:

\begin{abstract}
"Costuma-se dizer que o verdadeiro tribunal é a consciência, em que se deve julgar as coisas e ouvir a voz da verdade. Isso é fácil de dizer. Melanchthon afirmou essa coisa, assim como os outros, mas sentia em sua consciência que outro princípio era necessário para construir a Igreja... Será que se dẹve abrir as portas a qualquer um que se considere mensageiro de Deus?... Seja o que for, é preciso voltar à autoridade que nunca é segura nem legítima a não ser que venha de cima e não seja autoproclamada... Se Melanchthon houvesse entendido isso devidamente, nunca poderia imaginar que se pode separar a verdade do organismo em que foi depositada a sucessão e a autoridade legítima. A causa das mudanças que podemos observar nas comunidades separadas consiste no fato de que elas não reconhecem a autoridade da Igreja, a Promessa que ela recebeu de cima; em poucas palavras, elas não souberam o que é a Igreja... Os hereges foram então devolvidos ao raciocínio humano e às suas paixões particulares"'(7).
\end{abstract}

Em outras palavras, o diabo transformou a Reforma em Iluminismo, o que consistiu numa verdadeira façanha. Para reagir contra o perigo da teocracia - isto é, contra a corrupção da Igreja pelo poder secular (de um lado) e a supressão do potencial criativo humano (do outro) - Deus tinha que afrouxar a relação entre religião e política, e conceder a esta última uma certa autonomia (institucional, supomos, e não moral). $\mathrm{O}$ diabo penetrou nesse processo, desviando-o em duas direções que, no final, iam convergir. 
Ele favoreceu a estatização da religião e deu ao Iluminismo um forte aspecto anti-religioso, obrigando desse modo a política a produzir ex nihilo as suas próprias regras, e reduzindo-a a uma pura cobiça pelo poder.

7.

Para o diabo, os resultados não foram, no entanto, muito satisfatórios. Para conseguir seu objetivo, ele tinha que favorecer a liberdade, e a liberdade é divina, qualquer que seja sua exploração pelo diabo e a opinião de Lutero. A política, no momento em que começou a depender de si própria, teve que desistir da "verdade" como alicerce, em favor do "consenso". Esta é realmente a pedra angular da democracia; o "consenso" não implica de forma alguma que seus participantes sejam os benditos donos da verdade. A maioria deve governar, não porque tenha razão, mas porque ela é simplesmente a maioria.

Não era isso porém o que o diabo pretendia. Ao contrário do que provavelmente (e racionalmente) esperava, a política que devia construir seu próprio fundamento, em vez de o procurar nos mandamentos divinos, tornou-se menos e não mais cruel. (Evidentemente, o diabo deve consolar-se, pensando que este efeito desagradável seria o resultado da energia, sempre atuante, da herança religiosa; deixo sem resposta a questão, se esta explicação está certa.) E o dom divino da liberdade tinha mais, e não menos ocasiões de se expandir e fixar. O diabo foi obrigado a inventar uma nova contraforça e teve então uma idéia mais esperta do que todas as suas anteriores. E esta é a quarta fase da batalha que se está desenvolvendo em nosso século e que podemos todos observar.

O diabo decidiu voltar a uma velha concepção de política, baseada na "verdade" ao contrário do acordo ou do consenso. Inventou os Estados ideológicos, isto e, os Estados cuja legitimidade é baseada no fato de que os seus donos são os donos da verdade. Quando alguém se opõe a um desses Estados ou a seu sistema, é um inimigo da verdade. O pai da mentira usou a idéia da verdade como sua arma poderosa.

A verdade é, por definição, universal. Não é ligada a nação alguma, nem a Estado. A nação ou o Estado não são apenas a nação e o Estado, que tentam realizar os seus próprios interesses, defender-se, progredir, conquistar novos territórios, construir o império, etc. A nação ou o Estado carregam agora a verdade universal, assim como no tempo das Cruzadas.

O diabo é o macaco de Deus, como diziam os teólogos medievais. Inventando o Estado ideológico, ele produziu uma imitação caricatural da teocracia. De fato, a Nova Ordem ia ser muito mais sólida e completa do que qualquer antigo Estado cristão, por dispensar quaisquer distinções entre as autoridades seculares e religiosas, e por juntar o poder espiritual e o temporal num só lugar. Deu-lhe o diabo não só os instrumentos de coerção e educação, mas também toda a riqueza da nação e, na verdade, a própria nação. A teocracia (ou antes a "aleteiocracia" - o governo da verdade), atingiu num certo momento a forma quase perfeita.

Isto, evidentemente, mudou o caráter da guerra. Desde a Segunda Guerra Mundial, a maior parte das guerras foi feita em nome da verdade universal, o que significa que elas se tornaram guerras civis. Como na guerra civil não funcionam regras de condução da guerra, os prisioneiros são muitas vezes assassinados ou obrigados, sob a ameaça da morte, a passar para o lado inimigo, o que não é considerado traição porque desse modo estão simplesmente abandonando o erro em favor da verdade, e abraçar a verdade é só conversão ou iluminação. $\mathrm{O}$ conceito de traição também mudou seu sentido: pode-se aplicá-lo apenas em relação àqueles que rejeitam o lado que se considera o veículo da verdade.

Parece que, com sua nova invenção, obteve o diabo um sucesso admirável, mas há sinais que esse triunfo talvez seja de curta duração, apesar de todos os horrores que a brincadeira histórica causou. Apareceram Estados ideológicos, muitos dos quais mostraram uma resistência impressionante. Visivelmente, porém, eles atingiram a fase de decomposição. Aparentemente, ainda são a encarnação da verdade, o que lhes concede o princípio de legitimidade. Mas cada vez que querem mobilizar seus cidadãos, apelam não para a verdade universal, mas para os sentimentos nacionais, a glória imperial, a raison d'état, o ódio racial (este especialmente visível nos países ideocráticos comunistas). Eles estavam conseguindo isso, até certo ponto, mas esses sucessos mostram um abismo grotesco entre a realidade e o seu disfarce verbal. Ficou irreversivelmente patente que sua verdade é a impostura, mas admitir isso abertamente traria conseqüências desastrosas. Por isso recorrem às soluções inábeis e intermediárias, tapando assim a crise.
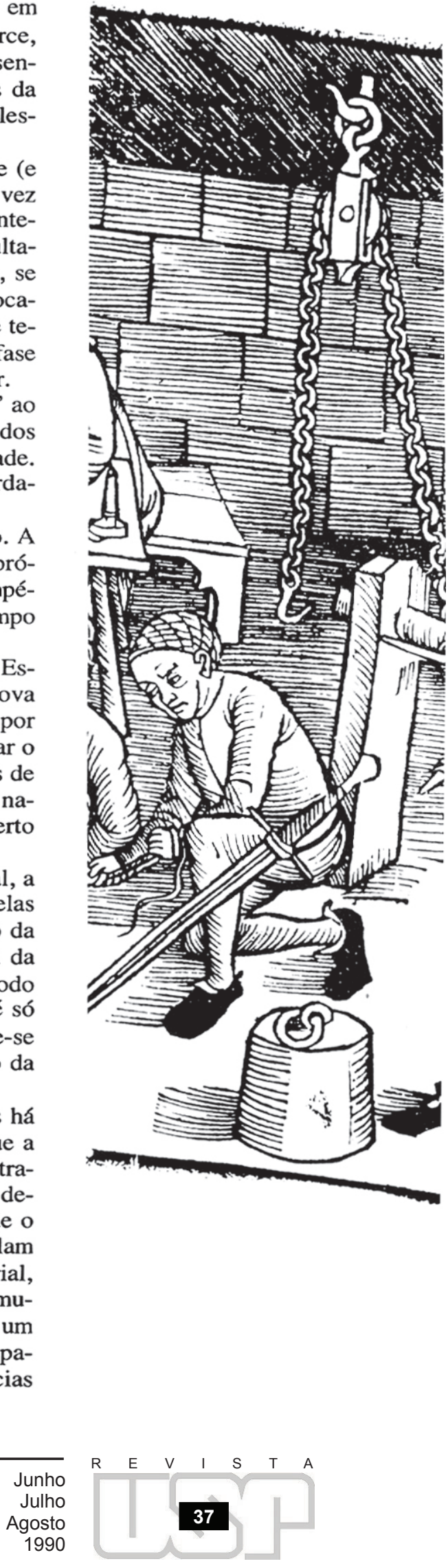
O diabo tem, com certeza, outros recursos. Além de construir bastiōes da verdade, ele tenta, às escondidas, introduzir de novo a verdade nas instituições democráticas, como alternativa para o contrato e o consenso. Ele toma o princípio da maioria e distorce-o, sugerindo uma idéia atraente, a idéia ç que a maioria como tal tem razão e por isso tem o direito de tudo fazer, inclusive de abolir o próprio princípio da maioria. Isso representa, como sabemos, um verdadeiro problema. Pode a constituição democrática cancelar-se a si mesma na base do consenso da maioria? Pode ficar anulada, isto é, cometer um suicídio, de acordo com os seus próprios princípios? (A pergunta análoga: pode o papa declarar infalivelmente que não é infalível?) Muitos pensadores refletiram sobre esse problema, desde Carl Schmitt (antes de se tornar nazista, evidentemente) até James Bachanan. Se a maioria como tal tem razão, então pode isso facilmente acontecer pois a minoria, como portadora do erro, merece a destruição.

Não acredito que o diabo vá conseguir, por meio de um desses métodos, eliminar a liberdade, isto $\varepsilon$, liquidar a existência humana. Os homens necessitam, sem dúvida, de segurança espiritual, o que os torna suscetíveis à tentação da ordem ideocrática, a tentação diabólica. Mas sentem também a necessidade de viver como seres humanos, ou seja, de usar a sua liberdade questionando a ordem existente, de desconfiar de cada verdade e de embrenhar-se nas inexploradas regiões do espírito. A necessidade de segurança não é uma necessidade especificamente humana; mas a necessidade do risco na exploração do desconhecido o é, sem dúvida.

Clausewitz fez a seguinte observação em sua obra clássica:

\begin{abstract}
"Apesar de o nosso intelecto sentir a inclinação para a claridade e a certeza, nosso espírito muitas vezes se inclina para a incerteza... ele prefere permanecer na imaginação, no reino do acaso e da sorte. Em vez de ficar na esfera da pura necessidade, embriaga-se com a riqueza de possibilidades; a coragem, assim animada, recebe asas e o espírito mergulha como um nadador impávido numa torrente, nos elementos da ousadia e do perigo... Em toda a parte existe então uma margem de casualidade, tanto nas coisas maiores, quanto nas mais pequenas. Se, de um lado, existe esse campo de casualidade, então, do outro, a coragem e a certeza devem existir em proporção a esse campo"(8).
\end{abstract}

Bem sabia Clausewitz do que estava falando. O que se aplica às guerras entre estados, aplica-se também às guerras entre o bem e o mal na história. Essa guerra provavelmente nunca vai acabar, dado que o material de que somos feitos alimenta os dois lados. Mesmo se a fase atual terminar com a frustração das intenções do diabo, ele será com certeza suficientemente esperto para abrir novas perspectivas à sua energia. Mas seria em vão especular sobre suas futuras invenções.

Este jogo interminável não é, com certeza, fonte de prazer intelectual. Santo Agostinho escrevia, É verdade, na Cidade de Deus (XI, 18), que Deus "enriquece o curso da história do mundo com uma espécie de antítese que oferece beleza a um poema... na composição da história do mundo existe uma beleza que surge do conflito dos opostos uma espécie de eloqüência em eventos, em vez de nas palavras". Hegel fez uma sinfonia similar da dialética histórica. Mas, depois de tudo que presenciamos em nosso século, somos antes propensos a pensar, com Kierkegaard, que a procura desse tipo de deleite estético e intelectual num grandioso panorama histórico é o mesmo que nos deliciarmos com o encanto da música que vem do touro de Phalaris (segundo a lenda, o tirano da Sicília, Phalaris, tinha um touro de bronze em que eram os seus inimigos queimados vivos; o touro foi construído com tal engenho que o horrível uivo das vítimas chegava, através da aparelhagem acústica, como uma melodia agradável).

Não, a luta entre o diabo e Deus na história não é um espetáculo divertido. Nosso único consolo vem do fato de que não somos observadores passivos, nem vítimas dessa luta, mas dela também participamos, e, por conseguinte, nosso destino se decide no campo em que corremos e jogamos. É trivial afirmar isso, mas, como muitas verdades triviais, vale a pena repeti-lo. 